\title{
CSNK2 in cancer: pathophysiology and translational applications
}

\author{
Scott W. Strum (iD ${ }^{1 凶}$, Laszlo Gyenis ${ }^{2}$ and David W. Litchfield $\mathbb{D}^{3 凶}$ \\ (c) The Author(s) 2021
}

Protein kinase CSNK2 (CK2) is a pleiotropic serine/threonine kinase frequently dysregulated in solid and hematologic malignancies. To consolidate a wide range of biological and clinically oriented data from this unique kinase in cancer, this systematic review summarises existing knowledge from in vitro, in vivo and pre-clinical studies on CSNK2 across 24 different human cancer types. CSNK2 mRNA transcripts, protein levels and activity were found to be routinely upregulated in cancer, and commonly identified phosphotargets included AKT, STAT3, RELA, PTEN and TP53. Phenotypically, it frequently influenced evasion of apoptosis, enhancement of proliferation, cell invasion/metastasis and cell cycle control. Clinically, it held prognostic significance across 14 different cancers, and its inhibition in xenograft experiments resulted in a positive treatment response in 12. In conjunction with commentary on preliminary studies of CSNK2 inhibitors in humans, this review harmonises an extensive body of CSNK2 data in cancer and reinforces its emergence as an attractive target for cancer therapy. Continuing to investigate CSNK2 will be crucial to advancing our understanding of CSNK2 biology, and offers the promise of important new discoveries scientifically and clinically.

British Journal of Cancer (2022) 126:994-1003; https://doi.org/10.1038/s41416-021-01616-2

\section{INTRODUCTION}

Phosphorylation is the most common type of reversible posttranslational modification in living cells [1], with protein kinases representing the enzymes that catalyse these phosphorylation events. Encoded by over 500 genes in the human genome [2, 3], protein kinases are estimated to phosphorylate well over $30 \%$ of all cellular proteins $[4,5]$. They can be classified based on the sequence homology of their catalytic domains into the following major groups: (1) Serine/Threonine kinases: AGC, CAMK, CMGC, STE, CK1; (2) Tyrosine kinases: TK, RGC and (3) TK-like kinases [6]. Protein kinases influence a wide variety of cellular functions including apoptosis, motility, growth, differentiation, proliferation and angiogenesis. Dysregulation of any one of these pathways can lead to significant maladaptation with outcomes ranging from cell death to neoplastic transformation.

As a class, protein kinases play important roles in health and disease [7]. In particular, they have been observed to influence the development of cancer, impacting virtually all aspects of oncogenesis [8]. This has led to the development of targeted therapies that have yielded significant advances in cancer treatment. To date, over 30 targeted therapies have been approved by the FDA to treat cancer covering all three kinase groups [9]. And ever since the first oncogene was discovered to be a kinase [10], increasing efforts have been made to develop smallmolecule inhibitors targeting these proteins. A classic example of this is evidenced by the drug imatinib (Gleevec), proven to be very effective in the treatment of CML. Borne from targeting the BCRAbl gene mutation highly prevalent in this malignancy, imatinib functions as a tyrosine kinase inhibitor that dramatically increases 5 -year survival rates to around $89 \%$ [11], compared to $30 \%$ without treatment [12]. Although efficacious in this setting, the kinase inhibition imparted by imatinib is not specific to BCR-Abl, which has subsequently been capitalised on to treat a series of other conditions such as systemic mastocytosis and KIT-positive GIST tumours [13].

Despite advances such as these, however, cancer often still holds a devastating prognosis. In 2018 it remained the second leading cause of death globally [14]. It is imperative that new treatment options become available to help broaden the armamentarium of therapies available to manage diseases that continue to have limited treatment options. One such targetable class of protein kinases that has been of growing interest over the last several decades has been the serine/threonine kinase CK2 (CSNK2).

Functionally crucial for cell development and commonly dysregulated in cancer, CSNK2 is a pleiotropic serine/threonine kinase encoded by two distinct catalytic isoforms (CSNK2A1 and CSNK2A2) that can form complexes with a regulatory subunit (CSNK2B). Belonging to the CMGC group of kinases, CSNK2 functions primarily as part of a tetrameric complex with two

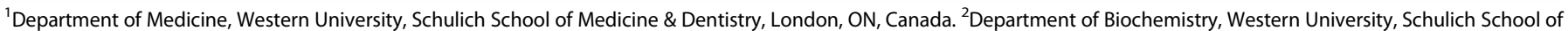

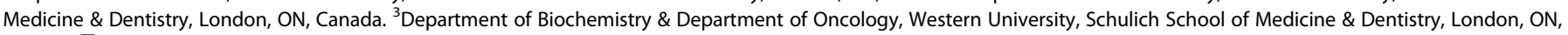
Canada. ${ }^{凶}$ email: sstrum@uwo.ca; litchfi@uwo.ca 
regulatory CSNK2B subunits, but it can also function independently in monomeric form. Each of the CSNK2A subunits is constitutively catalytically active, but their association with CSNK2B can change its functional properties such as its substrate specificity $[15,16]$, as well as subcellular localisation $[17,18]$. Further, independent functions of the CSNK2B subunit have also been described $[16,19,20]$.

CSNK2 kinase subunits have a unique minimum consensus sequence for phosphorylation of Ser-X-X-acidic [21], largely distinct from many other protein kinases [16]. They are generally found in the cytoplasm and nucleus, whose distribution varies between cell lines as well as under different physiologic conditions [22-24]. Its functionality is broad, potentially responsible for about $10 \%$ of the phosphoproteome based on the prevalence of phosphopeptides that conform to the CSNK2 recognition motif [25]. It is no surprise that its activity spans a multitude of signaling pathways including Wnt [26], JAK-STAT [27], PI3K/AKT $[28,29]$ and numerous others. As a result, its regulation becomes paramount in defining its roles in different biological contexts.

Regulatory mechanisms of CSNK2 are varied and remain relatively poorly understood, due at least in part to its constitutive activity when assayed in vitro. What is known of its regulation has been reviewed in Olsten et al 2005 [30] and Litchfield et al. 2003 [16]. Specific to CSNK2 in cancer, regulatory mechanisms previously studied have included localisation [31], scaffolding [32], regulation of CSNK2 subunit expression/assembly/localisation [33], post-translational modification [34] and small-molecule interactions [35]. Functionally, CSNK2 plays an important role in modulating cellular processes such as proliferation [21], signaling pathway activation [36], apoptosis [37], angiogenesis [38], growth [16] and metabolism [39]. Crucial for embryonic development in mouse models [40-42], dysregulation of CSNK2 can also lead to a series of disease states including inflammation [43], cardiomyopathy [44] and cancer.

Given the high incidence of cancer mortality worldwide [14], CSNK2 is an ideal target for further research as in vitro and in vivo studies have repeatedly shown it is dysregulated in both hematologic and solid malignancies $[45,46]$. Notably, Seldin and colleagues have shown that overexpression of CSNK2A1 leads to a stochastic propensity to developing lymphoma in mice [47]. Several other studies have reported its tumorigenic potential through upregulation of CSNK2 subunits as well [48-50]. Discoveries such as these, in combination with its widespread dysregulation in cancer, have made it a protein of interest not only for biological study, but also for disease management.

With growing evidence that CSNK2 plays an important role in cancer, efforts have been made over the last twenty years to target it for drug development. This has been facilitated in the part through the generation of CSNK2-specific inhibitors CX4945 and CIGB-300. CX4945 was developed in 2011 as the result of a structure-based optimzation of a candidate inhibitor that was highly selective, orally bioavailable, and demonstrated promise in preliminary xenograft experiments [51]. Its use has since expanded widely, and it was granted orphan drug status by the FDA in 2017 for the treatment of cholangiocarcinoma. Another notable CSNK2 inhibitor is CIGB-300, identified as the result of screening a random cyclic peptide phage display library for candidate drugs [52]. It has similarly since been used in numerous pre-clinical settings. In keeping with the paradigm shift of cancer treatment whereby isolated drivers of oncogenesis are specifically targeted for treatment (eg CDK4/6 inhibitors, MEK inhibitors, VEGF inhibitors), it is foreseeable that inhibitors of CSNK2 such as these may well represent the next wave of clinically efficacious smallmolecule therapeutics.

Building on the framework outlined above, this systematic review provides a summary of existing knowledge from in vitro and in vivo studies on CSNK2 mRNA/protein expression and activity levels, downstream phosphotargets, associated phenotypes, in vivo, and pre-clinical studies across a wide range of 24 different cancer types. Major trends are highlighted, balanced with commentary on the biologic complexity of this kinase. These results are then integrated to identify high-yield areas of CSNK2 inhibition that hold promise for therapeutic benefit. Our analysis supports CSNK2 as a potentially attractive target for cancer therapy and points to specific areas in which further investigation will be critical to advance our understanding of the biology and pathophysiology of CSNK2.

\section{PATHOPHYSIOLOGY OF CSNK2 IN CANCER}

CSNK2 is a constitutively active pleiotropic protein kinase involved in many homeostatic cellular processes, such as proliferation and cell division. Crucial for cell development, it has also been found to be frequently dysregulated in cancer $[45,46]$. Interestingly, despite this dysregulation, CSNK2 tends not to be heavily mutated in malignant cells. Using CBioPortal, CSNK2A1, CSNK2A2 and CSNK2B were found to harbor somatic mutation frequencies of only $0.8 \%$, $0.6 \%$ and $<0.1 \%$, respectively, the majority of which were found to occur with very low counts $[53,54]$. Using the COSMIC $[55]$ and CBioPortal databases $[53,54]$ along with CSNK2A1 as an example kinase subunit, mutations were identified across nearly the entire protein sequence, including sites within the nucleotide binding cluster, acidic loop, as well as the CSNK2B binding region. By contrast, the most frequent mutations were not found within any of these functional areas. Thus, the effect these mutations have on CSNK2 in oncogenesis remains uncertain, but may suggest they play a more minor role in its oncogenic potential than other factors.

More aptly, CSNK2 has demonstrated itself to be a central player in malignant cell biology through 'non-oncogene addiction' [56]. In non-oncogene addiction, dysregulation of a target protein helps sustain the activities necessary for cancer cell propagation. The pathophysiologic mechanisms that allow CSNK2 to drive these hallmarks of oncogenesis are therefore imperative to examine. We herein describe the overarching findings from a systematic review of the literature of CSNK2 targets identified in 24 unique cancers, extracting data on mRNA transcript, protein, kinase activity levels, phosphotargets, phenotypic behaviours and in vivo experiments. Detailed in the Supplementary Materials, data compiled in this review were collected from records of all years in PubMed up until May 2020 using PRISMA methodology (Appendix 1; Table 1 and Table 2 with corresponding references in Table S1 and Appendix 2; Table S2).

Among the first data collected in this review were biochemical changes influenced by CSNK2 in cancer (Table 1). Elevations in CSNK2 activity, protein levels and mRNA levels in malignant tissues relative to their non-malignant counterparts were very common. To provide a comparator arm using large-scale highthroughput studies, parallel external mRNA transcript and protein data from The Cancer Genome Atlas (TCGA) and CPTAC (Clinical Proteomic Tumor Analysis Consortium), respectively, were compiled through UALCAN [57] and incorporated into Table 1. The trend of general upregulation remained evident across this vast cross-section of data. Thus, widespread CSNK2 dysregulation, combined with data from prior studies that overexpression of CSNK2A1 can lead to in vivo oncogenic transformation [48-50], strongly suggests an important role in cancer.

Variation in the data certainly did exist, however. For example, CSNK2A1 transcript levels were decreased in thyroid cancer cells yet corresponding CSNK2A1 protein levels were increased. In prostate cancer cells, CSNK2A1 transcript levels were unchanged, yet its protein levels were increased. Such examples reinforce the complexity of CSNK2 biology. Intracellular localisation [33, 58], post-translational modification [34] and small-molecule interactions [35] represent but some of the putative mechanisms that 
Table 1. CSNK2 pathophysiologic data sorted by cancer type.

\begin{tabular}{|c|c|c|c|c|c|c|c|c|c|c|c|c|c|c|c|}
\hline \multirow{2}{*}{$\begin{array}{l}\text { Cancer Type } \\
\text { Bladder } \\
\text { Bone }\end{array}$} & \multicolumn{2}{|c|}{$\begin{array}{l}\text { CSNK2A1 } \\
\text { Protein } \\
\text { SR CPTAC }\end{array}$} & \multicolumn{2}{|c|}{\begin{tabular}{|l} 
CSNK2A2 \\
Protein \\
SR CPRAC
\end{tabular}} & \multicolumn{2}{|c|}{$\begin{array}{l}\text { CSNK2B } \\
\text { Protein } \\
\text { SR CPTAC }\end{array}$} & \multicolumn{2}{|c|}{$\left|\begin{array}{cc}\text { CSNK2A1 } \\
\text { Transcript } \\
\text { SR } & \text { TCGA }\end{array}\right|$} & \multicolumn{2}{|c|}{$\begin{array}{|cc|}\text { CSNK2A2 } \\
\text { SRanscript } \\
\text { TR } & \text { TCGA }\end{array}$} & \multicolumn{2}{|c|}{$\mid \begin{array}{c}\text { CSNK2B } \\
\text { Transcript } \\
\text { SR }\end{array}$} & \multirow[t]{2}{*}{$\begin{array}{c}\text { CSNK2 } \\
\text { Activity } \\
\text { SR }\end{array}$} & \multirow{2}{*}{$\begin{array}{l}\text { CSNK2 Phosphorylation Targets (SR) } \\
\text { AKT (2). HDAC2. } \\
\text { FGF1. SHOX. PLEKHO1. CAPZA1. MDC1. OTUB1. }\end{array}$} & \multirow{2}{*}{$\begin{array}{c}\text { CSNK2 Associated Phenotypes (SR) } \\
\text { Proliferation. Metabolism. Cell cycle. } \\
\text { Apoptosis (2). Proliferation* (2). Proliferation. }\end{array}$} \\
\hline & 슬 & & & & 슬 & & 숩 & 든 & & $\Leftrightarrow$ & & 숩 & & & \\
\hline Brain (GBM) & 合 & & & & & & 순 & $\Leftrightarrow$ & 음 & $\Leftrightarrow$ & 순 & 누 & 贯 & $\begin{array}{l}\text { AKT (2). RELA (2). PGK1. MTOR. MAPK1. CAST. CTNNB. PTEN. } \\
\text { SIRT1. IRF3. TBK1. PPP2CA. STAT3. STAT5. CTNNA. } \\
\end{array}$ & $\begin{array}{l}\text { Apoptosis (5). Proliferation (3). Evading growth } \\
\text { suppression (3). Invasion and migration. Cell cycle. }\end{array}$ \\
\hline Breast & 合 & 金 & & $\Leftrightarrow$ & & $\Leftrightarrow$ & 金 & 수 & $\sqrt{n}$ & 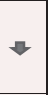 & 슨 & 슬 & 合 & $\begin{array}{l}\text { AKT (5). PGR (3). STAT3 (3). ESR1 (2). SIRT6 (2). RELA. MTOR. } \\
\text { CDKN1A. HIF1A. PTEN. CCDC106. MYH2. FOXC2. MAPK14. } \\
\text { MAPK8. IKBKE. NFKBIA. GPI. SLC39A7. HDAC2. SIX1. CTNNB. } \\
\text { IGFBP3. PRKAA2. PRKC. }\end{array}$ & $\begin{array}{l}\text { Invasion and migration (8). Apoptosis (5). Cell cycle (5). } \\
\text { Proliferation (4). Evading growth suppression (2). } \\
\text { Angiogenesis. }\end{array}$ \\
\hline Cervical & & & & & & & & 숩 & & $\sqrt{2}$ & & $\Leftrightarrow$ & & CCDC106. NPM1. & Apoptosis (3). Cell cycle. \\
\hline Cholangiocarcinoma & 合 & 点 & 을 & $\Leftrightarrow$ & 曾 & 눈 & 包 & 슴 & 슬 & 수 & 수 & 숩 & 뭉 & $\begin{array}{l}\text { AKT. } \\
\text { RIOK1. ECE1. TP53. HSP90. DUSP4. EIF5. CASTOR1. } \\
\text { TOP1. CTNNB. PRKAA2. }\end{array}$ & $\begin{array}{l}\text { Apoptosis (2). Proliferation (2). Evading growth } \\
\text { suppression. Invasion and migration. Cell cycle. } \\
\text { Proliferation (7). Apoptosis (4). Cell cycle (4). } \\
\text { Invasion and migration. Metabolism. }\end{array}$ \\
\hline Esophagus & & & & & 全 & & & 金 & & 合 & 金 & 숩 & & AKT. NCoR/SMRT. SNAI1. BIRC5. & Invasion and migration (2). Apoptosis (2). \\
\hline Gastric & 金 & & & & 시 & & ㄴ. & 슴 & & 다 & & 숨 & & RIOK1. PDCD5. CCAR2. ARC. XRCC1. AKT. MTOR. & $\begin{array}{l}\begin{array}{l}\text { Invasion and migration (4). Proliferation (2). DNA repair. } \\
\text { Apoptosis. }\end{array} \\
\end{array}$ \\
\hline Head \& neck & 畐 & & 붕 & & 순 & & & 숩 & & 合 & & 合 & 뭉 & RELA (2). CTTN. IKBKB. AKT. RPS6. CDKN1A. TWIST1. & $\begin{array}{l}\text { Proliferation (3). Invasion and migration (3). Evading } \\
\text { growth suppression (2). Cell cycle. Apoptosis. }\end{array}$ \\
\hline Leukemia - AML & 苗 & & & & & & 合 & & & & 슨 & & 도 & $\begin{array}{c}\text { HOXA9. RELA. STAT3. FOXO3. TP53. AKT. PDK1. FOXO1. BAD. } \\
\text { SET }\end{array}$ & Apoptosis (2). Cell cycle (2). Proliferation (2). \\
\hline Leukemia - CLL & 佱 & & & & 슨 & & & & & & & & 슴 & PTEN (4). AKT (2). USP7. STAT3. PRKCB, PRKCD. & $\begin{array}{l}\text { Apoptosis (2). Evading growth suppression (2). } \\
\text { Proliferation. }\end{array}$ \\
\hline Liver & 合 & & & & & & 보 & 슴 & 음 & 움 & 슨 & 슴 & 苗 & AKT (2). SEPTIN2. ASPH. TP53. TOP2A. IGFBP1. NFKBIA. & $\begin{array}{c}\text { Proliferation (3). Invasion and migration (2). } \\
\text { Apoptosis (2). Avoiding immune destruction. Cell cycle. }\end{array}$ \\
\hline Lung (NSLSC) & 合 & 点 & 순 & $\theta$ & & 숩 & & 드 & & $\Leftrightarrow$ & & 贯 & 슬 & AKT (2). PML (2). BRMS1. MTOR. RPS3. CDC37. DVL & $\begin{array}{l}\text { Apoptosis (2). Invasion and metastasis. } \\
\text { DNA repair. Cell cycle. }\end{array}$ \\
\hline $\begin{array}{l}\text { Melanoma } \\
\text { Mesothelioma }\end{array}$ & 술 & & & & & & 金 & 눕 & & 숨 & & $\Leftrightarrow$ & 뚠 & MAPK3/MAPK1. DUSP6. & \\
\hline Multiple myeloma & 合 & & & & 슨 & & & & & & & & 金 & STAT3 (3). RELA (2). TTI1. ETV7. AKT. BRD4. & Apoptosis (5). Proliferation. Evading growth suppression. \\
\hline NHL - Follicular & 全 & & & & 合 & & & & & & & & & & \\
\hline NHL - DLBCL & & & & & & & & & & & & & & RELA. CDC37. AKT. & Proliferation. Apoptosis. \\
\hline $\begin{array}{l}\text { Ovarian } \\
\text { Pancreatic }\end{array}$ & 会 & 合 & & $\Leftrightarrow$ & & 숩 & & $\Leftrightarrow$ & & $\Leftrightarrow$ & & $\Leftrightarrow$ & & $\begin{array}{l}\text { BMI1. AKT. STAT3. HES1. GLI1. XRCC1. MDC1. PTEN. } \\
\text { AKT. CDKN1A. HIF1A. AKT. GSK3B. L1CAM. }\end{array}$ & $\begin{array}{l}\text { Proliferation (3). Apoptosis (2). Invasion and migration. } \\
\text { Apoptosis (4). Cell cycle (2). Invasion and migration. } \\
\text { Angiogenesis. }\end{array}$ \\
\hline Prostate & 只 & & & & & & & $\Leftrightarrow$ & & $\theta$ & & $\Leftrightarrow$ & & $\begin{array}{l}\text { AKT (5). RELA (4). PML (2). PAK1 (2). AR (2). HHEX. NPM1. } \\
\text { CDC25. IGFBP3. PAWR. NKX3-1. NCOR/SMRT. STAT3. TP53. } \\
\text { Vitamin D3. CDKN1A. }\end{array}$ & $\begin{array}{l}\text { Apoptosis (15). Proliferation (5). Invasion and } \\
\text { migration (4). Cell cycle. Evading growth suppression. }\end{array}$ \\
\hline Renal & 을 & 욤 & & 우 & 合 & $\Leftrightarrow$ & 숭 & 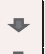 & 合 & 合 & 요 & 슬 & 畣 & CTNNB (2). VHL. CARD9. NFKBIA. STAT1. & $\begin{array}{c}\text { Apoptosis (2). Invasion and migration (2). Evading growth } \\
\text { suppression. Avoiding immune suppression. }\end{array}$ \\
\hline Thyroid & 至 & & & & & & & ( & & 合 & & 合 & & AKT. & \\
\hline
\end{tabular}

CSNK2 subunit transcript, protein and activity levels in cancer were reported as increased (up arrow), decreased (down arrow) or equivalent (sideways arrow). CSNK2 transcript and protein columns contained paired data: arrows in the left half of each column were data from publications identified in this systematic review (SR) (references in Table S1, with corresponding full citations in Appendix 2); arrows in the right half of each column represented external data from the TCGA or CPTAC, respectively (compiled by UALCAN [57]). All remaining data in Table 1 were derived strictly from this systematic review (SR). CSNK2 phosphotargets differentially regulated in cancer were listed, as well as CSNK2-associated cancer phenotypes. The number next to each phosphotarget or phenotype represented the number of supporting citations identified in this review (provided in brackets). Phosphotargets/phenotypes without a number were cited once.

*Proliferation correlated with decreased CSNK2 levels.

may account for these differences. Despite these variances, however, the overarching pattern was an elevation in CSNK2 activity, protein and transcript levels across a wide range of cancer types.

Mechanistically, five cancer-specific CSNK2 phosphotargets were identified in at least four or more cancer types: AKT, STAT3, RELA (NFkB), PTEN and TP53 (Table 1 with corresponding references in Table S1, Appendix 2; Fig. 1a). Each of these targets regulate processes directly related to hallmark oncology phenotypes [59]. The most heavily cited was AKT, identified in 17 of these cancers. Discovered 27 years ago, AKT is known to play a widespread role in cell survival, proliferation, metabolism, and growth, among others. As such, its functionality is exploited in cancer, demonstrated in part by the aberrant activation of AKT in $77 \%$ of all metastatic melanoma lesions [60] and $32 \%$ of all colorectal cancers [61]. Although the activity of AKT is influenced by many factors, CSNK2 exhibits site-specific phosphorylation of S129 that has been shown to positively regulate AKT's catalytic activity [28]. This specificity is important since other regulators of AKT, such as serine-threonine kinase GSK3A (a member of the same kinase family as CSNK2), phosphorylates T312 of AKT leading to activity attenuation instead of stimulation [62]. Thus, despite the pleiotropy of
CSNK2, it demonstrates a specificity that is likely very biologically significant.

At the phenotypic level, the most commonly cited behaviours influenced by CSNK2 in cancer were evasion of apoptosis (apoptosis), enhancement of proliferation (proliferation), enhancement of invasion/metastasis (invasion and metastasis), and cell cycle control (Table 1 with references in Table S1 and Appendix 2; Fig. 1b). Each of these were reported in 11 or more cancers. It was thus no surprise that they correlated heavily with commonly cited CSNK2-targets mentioned above. For example, AKT, PTEN and NFkB are known to regulate components of all four of these phenotypes. Although these were the most cited, virtually all phenotypic hallmarks of cancer were found to be influenced by CSNK2 in at least one context. Such examples included modulation of glucose metabolism in favor of maximal glycolytic capacity in colorectal cancer cells [63], and the upregulation of an important DNA-repair mechanism in gastric cancer cells with cisplatin-induced DNA damage [64].

In summary, it is clear that distinct biological patterns exist for CSNK2 in cancer. These patterns span a broad spectrum of biology, from modulating gene transcription to phenotypic behaviours. Although widespread patterns did exist, the role in CSNK2 in oncogenesis is complex and variation was present 
Table 2. CSNK2 inhibition in xenograft models sorted by cancer type.

\begin{tabular}{|c|c|c|c|c|}
\hline Cancer Type & $\begin{array}{l}\text { Engrafted Cell } \\
\text { Line : Host }\end{array}$ & Intervention & Results (Control vs Intervention) & $\begin{array}{l}\text { Reference } \\
\text { (Appendix 2) }\end{array}$ \\
\hline Bone & $\begin{array}{l}\text { 143B cells: } \\
\text { nude mice }\end{array}$ & CX4945 $150 \mathrm{mg} / \mathrm{kg}$ daily oral & $\begin{array}{l}\text { Survival lower }(p<0.05) \text { and tumour } \\
\text { size greater }(p<0.05) \text { in control } \\
\text { compared to CX4945 at study } \\
\text { endpoints }\end{array}$ & 193 \\
\hline Brain & $\begin{array}{l}\text { U3054MG cells: } \\
\text { SCID or nude } \\
\text { mice (female) }\end{array}$ & CX4945 75 mg/kg daily oral & $\begin{array}{l}\text { Growth at } 68 \text { days: no significant } \\
\text { difference between CX4945 and } \\
\text { control }\end{array}$ & 147 \\
\hline Brain & $\begin{array}{l}\text { U87MG cells: } \\
\text { nude mice }\end{array}$ & TBB $10 \mathrm{mg} / \mathrm{kg}$ q48 $\mathrm{h}$ intra-peritoneal & $\begin{array}{l}\text { Tumour mass at } 25 \text { days: } 650 \mathrm{mg} \text { vs } \\
125 \mathrm{mg}(p<0.05)\end{array}$ & 42 \\
\hline Brain & $\begin{array}{l}\text { U87MG cells: } \\
\text { SCID mice }\end{array}$ & $\begin{array}{l}\text { Engraftment of U87MG cells with CSNK2A knockdown } \\
\text { via induced CSNK2A shRNA }\end{array}$ & $\begin{array}{l}\text { Survival: } 20 \text { days vs }>40 \text { days }(p< \\
0.0009 \text { ) }\end{array}$ & 137 \\
\hline Brain & $\begin{array}{l}\text { X1046 cells: } \\
\text { nude mice }\end{array}$ & CX4945 $75 \mathrm{mg} / \mathrm{kg}$ BID oral for 28 days starting at day 5 & Survival: 38 days vs 59 days & 239 \\
\hline Breast & $\begin{array}{l}\text { MDA-MB-231 } \\
\text { cells: mice }\end{array}$ & $\begin{array}{l}\text { Tenfibgen siRNA-CSNK2 } 0.01 \mathrm{mg} / \mathrm{kg} \text { by tail vein } \\
\text { injection }\end{array}$ & $\begin{array}{l}\text { Tumour volume on day } 10 \text { relative to } \\
\text { day } 0: 2.1 \times \text { vs } 1.4 \times(p=0.026)\end{array}$ & 200 \\
\hline Breast & $\begin{array}{l}\text { MDA-MB-231 } \\
\text { cells: nude mice } \\
\text { (female) }\end{array}$ & $\begin{array}{l}\text { Tenfibgen siRNA-CSNK2 } 0.01 \mathrm{mg} / \mathrm{kg} \text { on day } 1,4,7 \text { by } \\
\text { tail vein injection }\end{array}$ & $\begin{array}{l}\text { Tumour volume on day } 10 \text { relative to } \\
\text { day } 0: 2.05 \times \text { vs } 1.35 \times(p<0.05)\end{array}$ & 97 \\
\hline Breast & $\begin{array}{l}\text { BT-474 cells: } \\
\text { nude mice } \\
\text { (female) }\end{array}$ & CX4945 $75 \mathrm{mg} / \mathrm{kg}$ BID oral & $\begin{array}{l}\text { Tumour volume at } 30 \text { days: } 650 \mathrm{~mm}^{3} \\
\text { vs } 190 \mathrm{~mm}^{3}(p<0.001)\end{array}$ & 183 \\
\hline $\begin{array}{l}\text { Head } \\
\text { and neck }\end{array}$ & $\begin{array}{l}\text { FaDu cells: } \\
\text { nude mice }\end{array}$ & $\begin{array}{l}\text { Tenfibgen s50 RNAi-CSNK2 } 10 \mathrm{mg} / \mathrm{kg} \text { twice } \mathrm{q} 48 \mathrm{~h} \text { by } \\
\text { tail vein injection }\end{array}$ & $\begin{array}{l}\text { Tumour volume at } 35 \text { days: } 1075 \mathrm{~mm}^{3} \\
\text { vs } 75 \mathrm{~mm}^{3}(p<0.0001)\end{array}$ & 204 \\
\hline $\begin{array}{l}\text { Head } \\
\text { and neck }\end{array}$ & $\begin{array}{l}\text { (A) UM-SCC } 11 \text { A } \\
\text { cells: SCID } \\
\text { mice (male) } \\
\text { (B) FaDu cells: } \\
\text { nude mice } \\
\text { (female) }\end{array}$ & $\begin{array}{l}\text { (A) Tenfibgen nanocapsules with anti-CSNK2A1/A2 at } \\
10 \mathrm{ug} / \mathrm{kg} \text { intra-peritoneal q3days. } \\
\text { (B) Tenfibgen nanocapsules with anti-CSNK2A1/A2 at } \\
10 \mathrm{ug} / \mathrm{kg} \text { IV q48 } \mathrm{h} \text { for } 2 \text { doses }\end{array}$ & $\begin{array}{l}\text { (A) Tumour volume at } 7 \text { days: } 620 \\
\mathrm{~mm}^{3} \text { vs } 250 \mathrm{~mm}^{3}(p<0.01) \\
\text { (B) Tumour volume at } 7 \text { days: } 180 \\
\mathrm{~mm}^{3} \text { vs } 50 \mathrm{~mm}^{3}(p<0.01)\end{array}$ & 18 \\
\hline $\begin{array}{l}\text { Leukemia- } \\
\text { CLL }\end{array}$ & $\begin{array}{l}\text { MO1043 cells: } \\
\text { nude mice }\end{array}$ & CX4945 75 mg/kg BID oral & $\begin{array}{l}\text { Tumour volume at } 13 \text { days: } 450 \mathrm{~mm}^{3} \\
\text { vs } 225 \mathrm{~mm}^{3}(p<0.001)\end{array}$ & 129 \\
\hline $\begin{array}{l}\text { Leukemia- } \\
\text { CLL }\end{array}$ & $\begin{array}{l}\text { MO1043 cells: } \\
\text { nude mice }\end{array}$ & $\begin{array}{l}\text { CIGB-300 } 20 \mathrm{mg} / \mathrm{kg} \text { intra-peritoneal for } 5 \text { days plus } \\
2 \text { days rest, then repeated }\end{array}$ & $\begin{array}{l}\text { Tumour volume at } 15 \text { days: } 1200 \mathrm{~mm}^{3} \\
\text { vs } 600 \mathrm{~mm}^{3}(p<0.001)\end{array}$ & 128 \\
\hline Liver & $\begin{array}{l}\text { HepG2 cells: } \\
\text { NMRI nude } \\
\text { mice (male) }\end{array}$ & DMAT $500 \mathrm{ug} / \mathrm{kg}$ daily intra-peritoneal & $\begin{array}{l}\text { Tumour volume at } 10 \text { days: } 600 \mathrm{~mm}^{3} \\
\text { vs } 200 \mathrm{~mm}^{3}(P<0.05)\end{array}$ & 169 \\
\hline Lung & $\begin{array}{l}\mathrm{H}-125 \text { cells: nude } \\
\text { mice (female) }\end{array}$ & $\begin{array}{l}\text { P15-Tat (ie CIGB-300) } 10 \mathrm{mg} / \mathrm{kg} \text { intra-peritoneal } \\
\text { for } 5 \text { days }\end{array}$ & $\begin{array}{l}\text { Survival: } 24 \text { days vs } 41 \text { days ( } p= \\
0.0002 \text { ) }\end{array}$ & 151 \\
\hline Ovarian & $\begin{array}{l}\text { SKOV3 EOC cells: } \\
\text { nude mice }\end{array}$ & CX4945 $75 \mathrm{mg} / \mathrm{kg}$ daily oral & $\begin{array}{l}\text { Tumour volume at } 21 \text { days: } 400 \mathrm{~mm}^{3} \\
\text { vs } 180 \mathrm{~mm}^{3}(p<0.01)\end{array}$ & 25 \\
\hline Ovarian & $\begin{array}{l}\text { IGORV-1 cells: } \\
\text { nude mice } \\
\text { (female) }\end{array}$ & CX4945 75 mg/kg daily oral & $\begin{array}{l}\text { Proliferative index at } 42 \text { days: } 37 \% \text { vs } \\
16 \%(p<0.001) \text {. Vascular tumur area } \\
\text { at } 42 \text { days: } 28 \% \text { vs } 14 \%(p<0.001) .\end{array}$ & 99 \\
\hline
\end{tabular}


Table 2 continued

\begin{tabular}{|c|c|c|c|c|}
\hline Cancer Type & $\begin{array}{l}\text { Engrafted Cell } \\
\text { Line : Host }\end{array}$ & Intervention & Results (Control vs Intervention) & $\begin{array}{l}\text { Reference } \\
\text { (Appendix 2) }\end{array}$ \\
\hline Pancreatic & $\begin{array}{l}\text { BxPC-3 cells: } \\
\text { nude mice } \\
\text { (female) }\end{array}$ & CX4945 $75 \mathrm{mg} / \mathrm{kg}$ BID oral & $\begin{array}{l}\text { Tumour volume at } 35 \text { days: } 850 \mathrm{~mm}^{3} \\
\text { vs } 190 \mathrm{~mm}^{3}(p<0.001)\end{array}$ & 183 \\
\hline Prostate & $\begin{array}{l}\text { 22Rv1 cells: SCID } \\
\text { mice (male) }\end{array}$ & $\begin{array}{l}\text { Tenfibgen RNAi-CSNK2 } 0.02 \mathrm{mg} / \mathrm{kg} \text { by tail vein } \\
\text { injection on days } 1,4,7\end{array}$ & $\begin{array}{l}\text { Tumour weight on day } 8: 1.1 \mathrm{~g} \\
\text { vs } 0.35 \mathrm{~g}\end{array}$ & 201 \\
\hline Prostate & $\begin{array}{l}\text { PC3-LN4 } \\
\text { cells: mice }\end{array}$ & $\begin{array}{l}\text { Tenfibgen RNAi-CSNK2 } 0.01 \mathrm{mg} / \mathrm{kg} \text { by tail vein } \\
\text { injection }\end{array}$ & $\begin{array}{l}\text { Tumour volume on day } 10 \text { relative to } \\
\text { day } 0: 12.2 \times \text { vs } 5.2 \times(p=0.005)\end{array}$ & 200 \\
\hline Prostate & $\begin{array}{l}\text { PC3-LN4: nude } \\
\text { mice (male) }\end{array}$ & DMAT 500ug $/ \mathrm{kg}$ daily intra-peritoneal for 6 days & $\begin{array}{l}\text { Ki-67 proliferation index on day } 7 \text { : } \\
60 \% \text { vs } 30 \%(p<0.002)\end{array}$ & 202 \\
\hline Prostate & $\begin{array}{l}\text { PC3 cells: } \\
\text { nude mice }\end{array}$ & TBB_-dosing regimen not disclosed & $\begin{array}{l}\text { Tumour volume at } 35 \text { days: } 325 \mathrm{~mm}^{3} \\
\text { vs } 125 \mathrm{~mm}^{3}(p<0.001)\end{array}$ & 232 \\
\hline Prostate & $\begin{array}{l}\text { PC3 cells: } \\
\text { nude mice }\end{array}$ & CX4945 75 mg/kg BID oral & $\begin{array}{l}\text { Tumour volume at } 25 \text { days: } 775 \mathrm{~mm}^{3} \\
\text { vs } 200 \mathrm{~mm}^{3}\end{array}$ & 153 \\
\hline Prostate & $\begin{array}{l}\text { PC3-LN4: nude } \\
\text { mice (male) }\end{array}$ & $\begin{array}{l}\text { Anti-sense CSNK2 } 16.5 \mathrm{ug} / \mathrm{kg} \text { daily for } 4 \text { doses intra- } \\
\text { peritoneal }\end{array}$ & $\begin{array}{l}\text { Tumour mass at } 13 \text { days: } 1000 \mathrm{mg} \text { vs } \\
300 \mathrm{mg}(p<0.05)\end{array}$ & 199 \\
\hline Prostate & $\begin{array}{l}\text { PC3-LN4: nude } \\
\text { mice (male) }\end{array}$ & Anti-sense CSNK2A1 20 ug once intra-tumour & $\begin{array}{l}\text { Tumour size at } 8 \text { days: } 4.25 \mathrm{~mm} \text { vs } \\
0.0 \mathrm{~mm}\end{array}$ & 187 \\
\hline
\end{tabular}

Representative experiments from each publication identified in this systematic review were highlighted. For each, the host organism (and sex, if specified) alongside the cancer cell line engrafted into the host was listed. Corresponding interventions were summarised, with results from the control and intervention groups recorded thereafter (absolute values were either quoted directly or their closest approximation listed). Statistical significance was provided when available. Numbered citations for all studies listed corresponded with references in Appendix 2 of the Supplementary Information.

throughout. Nonetheless, this repository of information offers exciting insights using systematically collected data that is specific to CSNK2 biology in cancer.

\section{TRANSLATIONAL APPLICATIONS OF CSNK2 IN CANCER}

As outlined in the previous section, CSNK2 is widely dysregulated in cancer and is well positioned to be a high-yield clinical target. As a prelude to clinical trials, numerous studies have been conducted on CSNK2 to investigate the efficacy of targeting it in vivo. Compiled in Table 2 and Table S1 (corresponding references in Appendix 2) are representative experiments from systematically collected data of xenograft experiments that employed various methods of CSNK2 inhibition or knockdown. The principal conclusion from these experiments was that, irrespective of methodology, downregulation of CSNK2 almost always yielded positive outcomes. For example, intra-peritoneal injection of P15-Tat (i.e. CIGB-300) in female nude mice engrafted with $\mathrm{H}-125$ human NSCLC cells resulted in an improvement in survival from 24 to 41 days compared to control ( $p=0.0002$ ) [65]. In another model, nude mice were engrafted with FaDu cells to create a hypopharyngeal SCC xenograft. After 35 days of treatment with RNAi-CSNK2 through tail injection, tumour volumes were $\sim 75 \mathrm{~mm}^{3}$ compared to $1075 \mathrm{~mm}^{3}$ in the control $(p<0.0001)$ [66]. Examples such as these provide a strong foundation on which to further the clinical study of CSNK2 inhibition.
The pre-clinical and clinical efficacy of CSNK2 inhibition or knockdown is likely context dependent, however. An excellent example of this was shown in a prostate cancer mouse xenograft model, where CSNK2A1 siRNA was delivered via a nanoparticle delivery system in PC3-LN4 engrafted mice, leading to a $>50 \%$ reduction in tumour volume at 10 days after the start of treatment $(p=0.005)$ [67]. In this same experiment, however, castrateresistant prostate cancer cells (22Rv1) did not show any significant reduction in tumour volume. This study offered evidence that the biological background of CSNK2 inhibition/knockdown may be crucial in defining treatment efficacy. Coupled with several other examples in Table 2, the efficacy of CSNK2 inhibition can be strongly context dependent and must be accounted for when selecting the highest-yield clinical targets for further investigation.

Overall, CSNK2 has demonstrated itself to be a promising preclinical target in several cancers. Due in part to these findings, several preliminary experiments utilising CSNK2 inhibition in humans have been published to date. In a preliminary study of 31 women with micro-invasive or pre-invasive cervical cancer, intra-lesional injections of increasing doses of CIGB-300 over 5 days led to $75 \%$ of patients experiencing a significant visible lesion reduction, and $19 \%$ experiencing a full histologic regression [68]. Furthermore, no maximum-tolerated dose or dose-limiting toxicity was seen. In yet another example, a visually striking case was shown in a compassionate treatment program for a patient with chemo-radio-refractory metastatic germinoma to the spine. 
a

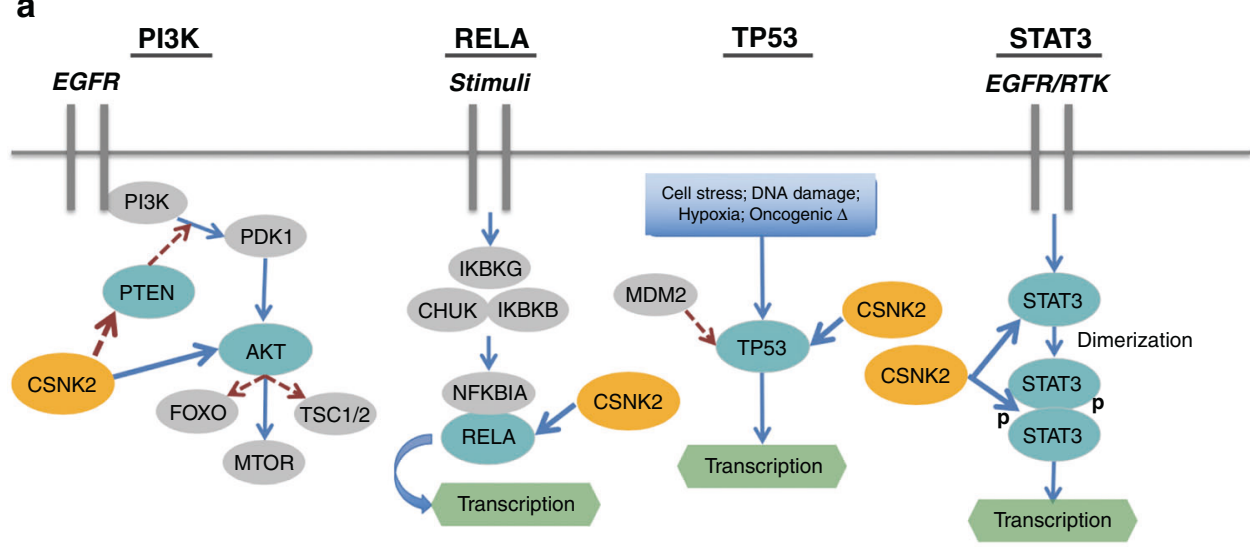

b

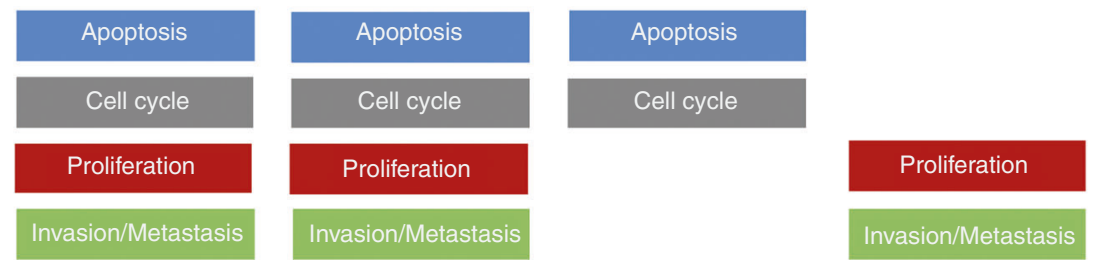

Fig. 1 CSNK2 phosphotargets, associated pathways, and CSNK2-regulated phenotypes identified in this review. a Graphical summary of the pathways from which the five most commonly cited CSNK2 targets across all cancers were identified in this review: AKT, PTEN, RELA (NFkB), TP53 and STAT3. Red dotted arrows indicate negative regulation. Blue arrows indicate all other interactions. b The four most common biological phenotypes associated with CSNK2 in cancer, categorised by cancer hallmark [59] were: apoptosis (A), proliferation (P), cell cycle control $(C)$ and invasion/metastasis (I). These four phenotypes were paired to the pathways from a if the pathway was an established regulator of this biological behaviour.

CIGB-300 was injected intra-lesionally, with a dramatic reduction in tumour volume after 7 days alongside an accompanying relief of symptoms, which was maintained for at least 1 year during the study's follow-up [69].

Formalised phase I and II clinical trials are underway to explore anti-CSNK2 therapies in the USA. Among them is NCT0212828, a phase I/II trial investigating the safety and preliminary efficacy of CX4945 in combination with cisplatin and gemcitabine in unresectable or metastatic cholangiocarcinoma. Anticipated study completion date is August 2021. Several other studies have been initiated, but not completed or their data remains unavailable publicly (Table 3). Further, no trials on CSNK2 were found through database searches of the EU Clinical Trials Register, Cancer Research UK Registry or Canadian Clinical Trials database. As such, there still remains a significant need to improve the knowledge around, and access to, CSNK2 inhibitor or knockdown therapies.

In addition to the therapeutic applications of CSNK2 modulation, there exist other areas in which this kinase has demonstrated clinical utility, namely that of diagnosis and prognostication. CSNK2 was found to hold prognostic significance in 14 of the cancers in this review (Table S1 with references in Appendix 2). Several were found to have diagnostic utility as well. For example, in clear cell renal cell carcinoma (RCC), Kaplan-Meier analysis of CSNK2A1 mRNA levels revealed a strong inverse correlation with overall survival $(p<0.01)$, TNM stage $(p=0.02)$ and metastasis $(p=0.003)$ [70]. In cholangiocarcinoma cells, Kaplan-Meier analysis of CSNK2B protein levels were inversely correlated with overall survival $(p=0.003)$ [71]. From a diagnostic perspective, a screen of sera from normal and ovarian cancer patients revealed that immunoglobulins to CSNK2 were present only in sera from cancer patients [72]. Identification of CSNK2-specific immunoglobulins may prove to be a useful cancer diagnostic or screening tool with appropriate validation. Such studies reveal much promise in the utility of CSNK2 in diagnosis and prognostication.

In summary, CSNK2 holds significant clinical potential. Evidenced primarily through xenograft mouse models, CSNK2 inhibition or knockdown consistently demonstrates positive outcomes. This is strongly supportive of the pathophysiologic role it plays in oncogenesis. By modulating cell behaviours such as apoptosis, the epithelial mesenchymal transition (EMT), drug efflux, DNA-damage repair mechanisms, and more [73], CSNK2 is positioned to be a high-yield target for clinical exploration and application. Further study is clearly needed to better characterise its full therapeutic and diagnostic/prognostic value.

\section{ADDITIONAL CONSIDERATIONS}

Over recent years, increasingly selective CSNK2 inhibitors have been used to improve the accuracy of scientific and pre-clinical studies such as CX4945 and CIGB-300. However, emerging data suggests that the use of these conventionally selective inhibitors may be less specific than previously thought. In a recent paper published by Wells et al. 2021 [74], a small library of highly selective pyrazolopyrimidine-based inhibitors significantly outperformed several conventional CSNK2 inhibitors in their selectivity in vitro. One of their highly selective compounds did not demonstrate anti-proliferative effects in the majority of cell lines tested, contrasting the widely held finding that CSNK2 is a universal driver of proliferation. As such, off-target effects of conventional inhibitors may have influenced results that were previously dependent on this method of CSNK2 inhibition, and must be considered when interpreting study outcomes. However, the use of conventional CSNK2 inhibitors as well as the targeted knockdown of CSNK2 in in vivo experiments have both demonstrated positive results in the xenograft setting (Table 2, with 
Table 3. Summary of oncology clinical trials identified within the NIH database that selectively targeted CSNK2.

\begin{tabular}{|c|c|c|c|c|c|}
\hline Cancer type & Study type & Population cohort & Intervention & Results & Reference \\
\hline Cholangiocarcinoma & $\begin{array}{l}\text { Phase I/II } \\
\text { Clinical Trial }\end{array}$ & $\begin{array}{l}\text { Unresectable or metastatic } \\
\text { cholangiocarcinoma }\end{array}$ & $\begin{array}{l}\text { Assessment of maximum tolerated } \\
\text { dose CX4945, then administered with } \\
\text { standard of care gemcitabine }+ \\
\text { cisplatin }\end{array}$ & $\begin{array}{l}\text { Anticipated } \\
\text { study } \\
\text { completion } \\
\text { August } 2021 \text {. }\end{array}$ & NCT02128282 \\
\hline Multiple myeloma & $\begin{array}{l}\text { Phase I } \\
\text { Clinical Trial }\end{array}$ & $\begin{array}{l}\text { Relapsed or refractory MM after } \\
\text { at least } 2 \text { lines of therapy }\end{array}$ & CX4945 QID—dose escalation study & $\begin{array}{l}\text { Study completed } \\
\text { September } 2011 .\end{array}$ & NCT01199718 \\
\hline Cervical & $\begin{array}{l}\text { Phase II } \\
\text { Clinical Trial }\end{array}$ & $\begin{array}{l}\text { Local application of CIGB-300 to } \\
\text { cervical adenocarcinoma or SCC }\end{array}$ & $\begin{array}{l}\text { CIGB-300 } 15 \text { mg, } 35 \text { mg, } 75 \text { mg locally } \\
\text { applied }\end{array}$ & $\begin{array}{l}\text { Study completed } \\
\text { August } 2016 .\end{array}$ & NCT01639625 \\
\hline
\end{tabular}

Cancer type, study phase, population, intervention, results and NCT number of the studies were listed. No oncology clinical trials targeting CSNK2 were identified in the EU Clinical Trials Register, Cancer Research UK Registry or Canadian Clinical Trials databases.

corresponding references in Appendix 2). Thus, the mechanisms by which small-molecule kinase inhibition and knockdown of CSNK2 may differ and must be accounted for when reconciling its biology, but they both harbor significant therapeutic potential.

CSNK2 has been identified as an excellent target for pre-clinical and clinical research, but the optimal application of its inhibition or knockdown remains largely unknown. One strategy that may maximise its potential is through co-administration with existing therapies. Doing so may facilitate increased anti-cancer efficacy, improved drug side effect tolerability at lower doses, and decreased resistance to chemotherapeutics. Multi-drug regimens that target pathways serially or in parallel to treat cancer have led to improved outcomes in several major clinical trials to date, such as melanoma $[75,76]$ and HER2 + metastatic breast cancer [77]. This strategy has already demonstrated efficacy in some xenograft models that employed CSNK2 inhibition [78]. Moreover, drawing on the findings of Wells and colleagues [74] that propose a narrower phenotypic spectrum of CSNK2 activity than previously thought, inhibition of CSNK2 may have a lower risk of cytotoxic side effects than may have been initially envisaged based on earlier conclusions that CSNK2 is essential for viability. Thus, CSNK2 remains a promising clinical target with boundless opportunity for exploration given the limited research conducted at this level to date.

In the era of PD-L1 and PD-1 inhibitors, a special note is made of the involvement of CSNK2 in this pathway. T-cells are an important component of the immune system's ability to target and destroy cancer cells, within which the T-cell receptor (TCR) pathway plays a crucial role in its activation. By contrast, the PD-1/ PD-L1 cascade helps to dampen T-cell activation, which cancer cells can take advantage of to evade host destruction. This mechanism begins with the recruitment of SHP phosphatase to PD-1 after its phosphorylation of several important cytoplasmic immunoreceptor motifs by Src kinases upon receptor stimulation [79]. SHP then dephosphorylates T-cell receptor proximal signaling components including CSNK2, PI3K/AKT, PTEN and RAS/MEK/ERK. As a result, T-cell proliferation, survival and cytokine production are inhibited, leading to lymphocyte exhaustion. In a simultaneous fashion, PD-1 also inhibits the stabilising effects of CSNK2-derived phosphorylation of PTEN, leading to downregulation of the PI3K/ AKT pathway. Since the stimulation of PI3K/AKT and RAS/MEK/ERK pathways are co-required for T-cell activation, this effect further reduces T-cell activation [80]. Thus, the PD-1 pathway has a significant influence on CSNK2 and its effectors.

The net effect of systemic inhibition of CSNK2 in a cancer patient on PD-L1 or PD-1 inhibitors remains unclear, however. Downregulation of CSNK2 using therapies such as CX4945 or CIGB-300 on T-cells may theoretically negate some of the desired effects of PD-1/PD-L1 inhibitors. However, their systemic administration would likely be balanced against its effects on both other types of immune cells and the cancer itself. CSNK2 is known to influence the immune system and has been shown to increase immune-mediated destruction of cancer cells in several studies [81-84]. As a whole, identifying which pathways CSNK2 are implicated in will help in the focused exploration of its pathogenesis in multiple cells types, and may improve the selection of optimal pre-clinical and clinical therapeutic strategies. The information contained within this review serves as one anchoring repository of such data.

Lastly, and from a technical standpoint, the data and conclusions from this publication did have limitations and potential bias. The number of citations for each cancer was variable, with small cell lung cancer, parathyroid cancer, Hodgkin's lymphoma, anal cancer, uterine cancer, testicular cancer and vulvar cancer being excluded from this review due to their paucity of data from preliminary searches. Another limitation was the observation that large knowledge deficits in specific aspects of CSNK2 biology exist. Such areas included CSNK2 post-translational modifications, subunit expression variation patterns and upstream regulatory mechanisms. Filling these gaps may lead to exciting new insights into CSNK2 pathophysiology. Third and lastly, by virtue of this review being systematic, certain studies were not included at the expense of utilising an unbiased approach to data collection. Nonetheless this affords the data strength in reducing bias not often seen in prior reviews of this kinase.

\section{CONCLUSION}

Over 500 kinases are encoded in the human genome, which have been implicated in virtually all aspects of cellular function [2]. Targeting kinases has led to significant advancements in cancer treatment, representing the second-most common family of druggable targets, surpassed only by GPCRs [9]. Given their constitutive activity, diverse phosphoproteome, and distinct phosphorylation consensus sequence, CSNK2 has many distinguishable features. In this systematic review of 24 hematologic and solid malignancies, CSNK2 was shown to have readily identifiable patterns of pathophysiologic behaviour, and its inhibition has proven promising in animal models and several pre-clinical studies.

CSNK2 mRNA transcript, protein, and activity levels were found to be regularly elevated in cancer cells, evidenced from both data in this systematic review as well as data from the TCGA and CPTAC (as compiled by UALCAN [57]). Of the cancer-associated CSNK2 phosphotargets, AKT, STAT3, RELA (NFkB), PTEN and p53 were identified in four or more cancers (Table 1 with references in Table S1 and Appendix 2; Fig. 1). The most commonly cited phenotypes associated with CSNK2 in cancer were apoptosis, 
proliferation, invasion and metastasis and cell cycle control (Table 1 with corresponding references in Table S1, Appendix 2). There was considerable overlap between the studied CSNK2 targets \& associated pathways, allowing for reconciliation of biochemical and microscopic behaviours. These trends help consolidate our understanding CSNK2 pathophysiology in cancer, but also may yield key insights into targeted clinical applications of its inhibition, such as small-molecule drugs that target parallel or serial pathways that CSNK2 is known to be implicated within the setting of cancer.

In summary, CSNK2 has proven to be an exciting kinase with unique pathophysiology and promising pre-clinical/clinical applications. Exploration of the utility of CSNK2 inhibition will likely offer new treatment strategies across multiple hematologic and solid malignancies in the coming years. It is anticipated that advancing our understanding CSNK2 biology will synergise with clinical data to empower the design of targeted treatment strategies to advance treatment options for disease, enabled in part by data such as that presented within this review. In combination with parallel studies and expert advice, targeted experiments may help to drive the discovery of new applications for CSNK2 inhibition that will positively impact patient lives.

\section{DATA AVAILABILITY}

All data presented in this review have been made available through the supplemental appendices and tables.

\section{REFERENCES}

1. Khoury GA, Baliban RC, Floudas CA. Proteome-wide post-translational modification statistics: frequency analysis and curation of the swiss-prot database. Sci Rep. 2011;1:90.

2. Manning G, Whyte $D$, Martinez $R$, Hunter $T$, Sudarsanam $S$. The protein kinase complement of the human genome. Science. 2002;298:1912-1916.

3. Sharma K, D'Souza RCJ, Tyanova S, Schaab C, Wisniewski JR, Cox J, et al. Ultradeep human phosphoproteome reveals a distinct regulatory nature. Cell Rep. 2014;8:1583-1594.

4. Ahn NG, Resing KA. Toward the phosphoproteome. Nat Biotechnol. 2001;19:317-318.

5. Wilhelm M, Schlegl J, Hahne H, Gholami AM, Lieberenz M, Savitscki MM, et al. Mass-spectrometry-based draft of the human proteoma. Nature. 2014;509:582-587.

6. Hanks S, Hunter T. Protein kinases 6 . The eukaryotic protein kinase superfamily: kinase (catalytic) domain structure and classification. FASEB J. 1995;9:576-596.

7. St-Denis NA, Litchfield DW. From birth to death: the role of protein kinase CK2 in the regulation of cell proliferation and survival. Cell Mol Life Sci. 2009;66:1817-1829.

8. Gross S, Rahal R, Stransky N, Lengauer C, Hoeflich KP. Targeting cancer with kinase inhibitors Find the latest version: targeting cancer with kinase inhibitors. J Clin Invest. 2015;125:1780-1789.

9. Bhullar KS, Lagarón NO, McGowan EM, Parmar I, Jha A, Hubbard BP, et al. Kinasetargeted cancer therapies: progress, challenges and future directions. Mol Cancer. 2018;17:1-20.

10. Collett MS, Erikson RL. Protein kinase activity associated with the avian sarcoma virus src gene product. PNAS. 1978;75:2021-2024.

11. Druker BJ, Guilhot F, O'Brien SG, Gathmann I, Kantarjian H, Gattermann N, et al. Five-year follow-up of patients receiving imatinib for chronic myeloid leukemia. $\mathrm{N}$ Engl J Med. 2006;355:2408-2417.

12. Pray L. Gleevec: the Breakthrough in Cancer Treatment. Nat Educ. 2008;1:37.

13. Iqbal N, Iqbal, N. Imatinib: a breakthrough of targeted therapy in cancer. Chemother Res Pract. 2014;2014:1-9.

14. WHO. Cancer [Internet] 2018. 2020. https://www.who.int/news-room/fact-sheets/ detail/cancer. Accessed Sept 20, 2020.

15. Pinna $L$. The raison d'être of constitutively active protein kinases: the lesson of CK2. Acc Chem Res. 2003;36:378-384.

16. Litchfield DW. Protein kinase CK2: structure, regulation and role in cellular decisions of life and death. Biochem J. 2003;369:1-15.

17. Sarrouilhe D, Filhol O, Leroy D, Bonello G, Baudry M, Chambaz E, et al. The tight association of protein kinase CK2 with plasma membranes is mediated by a specific domain of its regulatory beta-subunit. Biochim Biophys Acta. 1998;1403:199-210.
18. Rodriguez F, Contreras C, Bolanos-Garcia V, Allende J. Protein kinase CK2 as an ectokinase: the role of the regulatory CK2beta subunit. PNAS. 2008;105:5693-5698.

19. Bibby AC, Litchfield DW. The multiple personalities of the regulatory subunit of protein kinase CK2: CK2 dependent and CK2 independent roles reveal a secret identity for CK2 $\beta$. Int J Biol Sci. 2005;1:67-79.

20. Bolanos-Garcia V, Fernandez-Recio J, Allende J, Blundell T. Identifying interaction motifs in CK2beta-a ubiquitous kinase regulatory subunit. Trends Biochem Sci. 2006;31:654-661.

21. Pinna L, Meggio F. Protein kinase CK2 ("casein kinase-2") and its implication in cell division and proliferation. Prog Cell Cycle Res. 1997;3:77-97.

22. Filhol O, Nueda A, Martel V, Gerber-Scokaert D, Benitez MJ, Souchier C, et al. Livecell fluorescence imaging reveals the dynamics of protein kinase $C K 2$ individual subunits. Mol Cell Biol. 2003;23:975-987.

23. Pluemsampant S, Safronova OS, Nakahama KI, Morita I. Protein kinase CK2 is a key activator of histone deacetylase in hypoxia-associated tumors. Int J Cancer. 2008;122:333-341.

24. Gerber DA, Souquere-Besse S, Puvion F, Dubois MF, Bensaude O, Cochet C. Heatinduced relocalization of protein kinase CK2: Implication of CK2 in the context of cellular stress. J Biol Chem. 2000;275:23919-23926.

25. Salvi M, Sarno S, Cesaro L, Nakamura H, Pinna LA. Extraordinary pleiotropy of protein kinase CK2 revealed by weblogo phosphoproteome analysis. Biochim Biophys Acta. 2009;1793:847-859.

26. Dominguez I, Sonenshein GE, Seldin DC. CK2 and its role in Wnt and NF-KB signaling: linking development and cancer. Cell Mol Life. 2009;66:1850-1857.

27. Zheng Y, Qin H, Frank S, Deng L, Litchfield D, Tefferi A, et al. ACK2-dependent mechanism for activation of the JAK-STAT signaling pathway. Blood. 2011;118:156-166.

28. Di Maira G, Salvi M, Arrigoni G, Marin O, Sarno S, Brustolon F, et al. Protein kinase CK2 phosphorylates and upregulates Akt/PKB. Cell Death Differ. 2005;12:668-677.

29. Park JH, Kim JJ, Bae YS. Involvement of PI3K-AKT-mTOR pathway in protein kinase CKII inhibition-mediated senescence in human colon cancer cells. Biochem Biophys Res Commun. 2013;433:420-425.

30. Olsten ME, Weber JE, Litchfield DW. CK2 interacting proteins: emerging paradigms for CK2 regulation? Mol Cell Biochem. 2005;274:115-124.

31. Yamane K, Kinsella TJ. CK2 inhibits apoptosis and changes its cellular localization following ionizing radiation. Cancer Res. 2005;65:4362-4367.

32. Rozovski U, Harris DM, Li P, Liu Z, Jain P, Veletic I, et al. Constitutive phosphorylation of STAT3 by the CK2-BLNK-CD5 complex. Mol Cancer Res. 2017;15:610-618.

33. Golden D, Cantley L. Casein Kinase 2 prevents mesenchymal transformation by maintaining Foxc2 in the cytoplasm. Oncogene. 2015;34:4702-4712.

34. Seldin DC, Landesman-Bollag E, Farago M, Currier N, Lou D, Dominguez I. CK2 as a positive regulator of Wnt signalling and tumourigenesis. Mol Cell Biochem. 2005;274:63-67.

35. Wang F, Chang JT-H, Kao CJ, Huang RS. High expression of miR-532-5p, a tumor suppressor, leads to better prognosis in ovarian cancer both in vivo and in vitro. Physiol Behav. 2016;15:1123-1131.

36. Duncan JS, Litchfield DW. Too much of a good thing: the role of protein kinase CK2 in tumorigenesis and prospects for therapeutic inhibition of CK2. Biochim Biophys Acta. 2008;1784:33-47.

37. Ahmad KA, Wang G, Unger G, Slaton J, Ahmed K. CK2-a key suppressor of apoptosis. Adv Enzym Regul. 2008;48:179-187.

38. Kramerov A, Saghizadeh M, Caballero S, Shaw L, Calzi S, Bretner M, et al. Inhibition of protein kinase CK2 suppresses angiogenesis and hematopoietic stem cell recruitment to retinal neovascularization sites. Mol Cell Biochem. 2008;316:177-186.

39. Al Quobaili F, Montenarh M. CK2 and the regulation of the carbohydrate metabolism. Metabolism. 2012;61:1512-1517.

40. Lou DY, Dominguez I, Toselli P, Landesman-Bollag E, O'Brien C, Seldin DC. The alpha catalytic subunit of protein kinase $C K 2$ is required for mouse embryonic development. Mol Cell Biol. 2008;28:131-139.

41. Buchou T, Vernet M, Blond $\mathrm{O}$, Jensen $\mathrm{HH}$, Pointu $\mathrm{H}$, Olsen BB, et al. Disruption of the regulatory subunit of protein kinase $C K 2$ in mice leads to a cell-autonomous defect and early embryonic lethality. Mol Cell Biol. 2003;23:908-915.

42. Seldin DC, Lou DY, Toselli P, Landesman-Bollag E, Dominguez I. Gene targeting of CK2 catalytic subunits. Mol Cell Biochem. 2008;316:141-147.

43. Singh NN, Ramji DP. Protein kinase CK2, an important regulator of the inflammatory response? J Mol Med. 2008;86:887-897.

44. Eom GH, Cho YK, Ko JH, Shin S, Choe N, Kim Y, et al. Casein kinase-2a1 induces hypertrophic response by phosphorylation of histone deacetylase 2 S394 and its activation in the heart. Circulation. 2011;123:2392-2403.

45. Ruzzene M, Pinna LA. Addiction to protein kinase CK2: a common denominator of diverse cancer cells? Biochim Biophys Acta. 2010;1804:499-504.

46. Trembley JH, Chen Z, Unger G, Slaton J, Kren BT, Van Waes C, et al. Emergence of protein kinase CK2 as a key target in cancer therapy. BioFactors. 2010;36:187-195. 
47. Seldin DC, Leder P, Seldin DC, Leder P. Casein kinase lla transgene-induced murine lymphoma: relation to theileriosis in cattle. Science. 1995;267:894-897.

48. Channavajhala $P$, Seldin DC. Functional interaction of protein kinase CK2 and c-Myc in lymphomagenesis. Oncogene. 2002;21:5280-5288.

49. Landesman-Bollag E, Romieu-Mourez R, Song DH, Sonenshein GE, Cardiff RD, Seldin DC. Protein kinase CK2 in mammary gland tumorigenesis. Oncogene. 2001;20:3247-3257.

50. Kelliher MA, Seldin DC, Leder P. Tal-1 induces T cell acute lymphoblastic leukemia accelerated by casein kinase Ilalpha. EMBO J. 1996;15:5160-5166.

51. Siddiqui-Jain A, Drygin D, Streiner N, Chua P, Pierre F, O'Brien SE, et al. CX-4945, an orally bioavailable selective inhibitor of protein kinase CK2, inhibits prosurvival and angiogenic signaling and exhibits antitumor efficacy. Cancer Res. 2010;70:10288-10298.

52. Perea SE, Reyes O, Puchades Y, Mendoza O, Vispo NS, Torrens I, et al. Antitumor effect of a novel proapoptotic peptide that impairs the phosphorylation by the protein kinase 2 (casein kinase 2). Cancer Res. 2004;64:7127-7129.

53. Cerami E, Goa J, Ugur D, Gross BE, Sumer SO, Aksoy $Y$, et al. The cBio Cancer Genomics Portal: An open platform for exploring multidimensional cancer genomics data. Cancer Discov. 2012;2:401-404.

54. Goa J, Aksoy Y, Dogrusoz U, Dressing GE, Gross BE, Sumer SO, et al. Integrative analysis of complex cancer genomics and clinical profiles using the cBioPortal. Sci Signal. 2013;6:11.

55. Tate JG, Bamford S, Jubb HC, Sondka Z, Beare DM, Bindal N, et al. COSMIC: the Catalogue Of Somatic Mutations In Cancer. Nucleic Acids Res. 2019;47:D941-947.

56. Luo J, Solimini NL, Elledge SJ. Principles of cancer therapy: oncogene and nononcogene addiction. Cell. 2009;136:832-837.

57. Chandrashekar DS, Bashel B, Balasubramanya SAH, Creighton CJ, PonceRodriguez I, Chakravarthi BVSK, et al. UALCAN: A portal for facilitating tumor subgroup gene expression and survival analyses. Neoplasia. 2017;19:649-658.

58. Qaiser F, Trembley JH, Sadiq S, Muhammad I, Younis R, Hashmi SN, et al. Examination of CK2a and NF-KB p65 expression in human benign prostatic hyperplasia and prostate cancer tissues. Mol Cell Biochem. 2016;420:43-51.

59. Hanahan D, Weinberg RA. Hallmarks of cancer: the next generation. Cell. 2011;144:646-674.

60. Dai DL, Martinka M, Li G. Prognostic significance of activated Akt expression in melanoma: a clinicopathologic study of 292 cases. J Clin Oncol. 2005:23:1473-1482.

61. Silva-Pavez E, Villar $P$, Trigo $C$, Caamaño $E$, Niechi I, Pérez $P$, et al. CK2 inhibition with silmitasertib promotes methuosis-like cell death associated to catastrophic massive vacuolization of colorectal cancer cells. Cell Death Dis. 2019;10:73.

62. Gulen MF, Bulek K, Xiao H, Yu M, Gao J, Sun L, et al. Inactivation of the enzyme GSK3alpha by the kinase IKKi promotes AKT-mTOR signaling pathway that mediates Interleukin-1- induced Th17 cell maintenance. Immunity. 2012;37:800-812.

63. Yang KM, Kim K. Protein kinase CK2 modulation of pyruvate kinase $M$ isoforms augments the Warburg effect in cancer cells. J Cell Biochem. 2018;119:8501-8510.

64. Xu W, Chen Q, Wang Q, Sun Y, Wang S, Li A, et al. JWA reverses cisplatin resistance via the CK2-XRCC1 pathway in human gastric cancer cells. Cell Death Dis. 2014;5:1-11.

65. Perera Y, Farina HG, Hernández I, Mendoza O, Serrano JM, Reyes O, et al. Systemic administration of a peptide that impairs the Protein Kinase (CK2) phosphorylation reduces solid tumor growth in mice. Int J Cancer. 2008;122:57-62.

66. Unger G, Kren B, Korman V, Kimbrough T, Vogel R, Ondrey F, et al. Mechanism and efficacy of sub-50 nm tenfibgen nanocapsules for cancer cell-directed delivery of anti-CK2 RNAi to primary and metastatic squamous cell carcinoma. Mol Cancer Ther. 2014;13:2018-2029.

67. Trembley JH, Kren BT, Abedin MJ, Vogel RI, Cannon CM, Unger GM, et al. CK2 molecular targeting-tumor cell-specific delivery of RNAi in various models of cancer. Pharmaceuticals. 2017;10:4-7.

68. Solares AM, Santana A, Baladrón I, Valenzuela C, González CA, Díaz A, et al. Safety and preliminary efficacy data of a novel Casein Kinase 2 (CK2) peptide inhibitor administered intralesionally at four dose levels in patients with cervical malignancies. BMC Cancer. 2009;9:1-9.

69. Perea SE, Baladrón I, Garcia Y, Perera Y, Lopez A, Soriano JL, et al. CIGB-300, a synthetic peptide-based drug that targets the CK2 phosphoaceptor domain. Translational and clinical research. Mol Cell Biochem. 2011;356:45-50.

70. Rabjerg M, Bjerregaard H, Halekoh U, Jensen BL, Walter S, Marcussen N. Molecular characterization of clear cell renal cell carcinoma identifies CSNK2A1, SPP1 and DEFB1 as promising novel prognostic markers. APMIS. 2016;124:372-383.

71. Zhou F, Xu J, Ding G, Cao L. Overexpressions of CK2 $\beta$ and XIAP are associated with poor prognosis of patients with cholangiocarcinoma. Pathol Oncol Res. 2014;20:73-79.
72. Chatterjee M, Mohapatra S, lonan A, Bawa G, Ali R, Wang X, et al. Diagnostic markers of ovarian cancer by high-throughput antigen cloning and detection on arrays. Cancer Res. 2006;66:1181-1190.

73. Borgo C, Ruzzene M. Role of protein kinase CK2 in antitumor drug resistance. J Exp Clin Cancer Res. 2019;38:1-15.

74. Wells $\mathrm{Cl}$, Drewry DH, Pickett JE, Tjaden A, Krämer A, Müller S, et al. Development of a potent and selective chemical probe for the pleiotropic kinase CK2. Cell Chem Biol. 2021;28:546-558.

75. Schadendorf D, Dummer R, Smylie M, Rutkowski P, Ferrucci PF, Hill A, et al. Combined nivolumab and ipilimumab or monotherapy in untreated melanoma. N Engl J Med. 2015;373:23-34.

76. Long GV, Stroyakovsky DL, Gogas H, Levchenko E, de Braud F, Larkin JMG, et al. COMBI-d: A randomized, double-blinded, Phase III study comparing the combination of dabrafenib and trametinib to dabrafenib and trametinib placebo as first-line therapy in patients (pts) with unresectable or metastatic BRAFV600E/K mutation-positive cutaneous melanoma. J Clin Oncol. 2014;32:9011.

77. Swain S, Baselga J, Kim S, Ro J, Semiglazov V, Campone M, et al. Pertuzumab, trastuzumab, and docetaxel in HER2-positive metastatic breast cancer. N Engl J Med. 2015:372:724-734.

78. Siddiqui-Jain A, Bliesath J, Macalino D, Omori M, Huser N, Streiner N, et al. CK2 inhibitor CX-4945 suppresses DNA repair response triggered by DNA-targeted anticancer drugs and augments efficacy: mechanistic rationale for drug combination therapy. Mol Cancer Ther. 2012;11:994-1005.

79. García-Aranda M, Redondo M. Targeting protein kinases to enhance the response to anti-PD-1/PD-L1 Immunotherapy. Int J Mol Sci. 2019;20:2296.

80. Bardhan, K, Anagnostou, T, Boussiotis, VA. The PD1:PD-L1/2 pathway from discovery to clinical limplementation. Front Immunol. 2016;7:550.

81. Ulges A, Klein M, Reuter S, Gerlitzki B, Hoffmann M, Grebe N, et al. Protein kinase CK2 enables regulatory $T$ cells to suppress excessive $T H 2$ responses in vivo. Nat Immunol. 2015;16:267-275.

82. Jang SW, Hwang SS, Kim HS, Lee KO, Kim MK, Lee W, et al. Casein kinase 2 is a critical determinant of the balance of Th17 and Treg cell differentiation. Exp Mol Med. 2017;49:e375-e375.

83. Gibson SA, Benveniste EN. Protein kinase CK2: an emerging regulator of immunity. Trends Immunol. 2018;39:82-85.

84. Husain $\mathrm{K}$, Williamson $\mathrm{T}$, Nelson $\mathrm{N}$, Ghansah T. Protein kinase 2 (CK2): a potential regulator of immune cell development and function in cancer. Immunol Med. 2021;44:159-174.

\section{ACKNOWLEDGEMENTS}

An abstract of this work has been published online for the American Society for Clinical Oncology (ASCO) Annual Meeting, 2020 (Strum S, Gyenis L, Litchfield DW. JCO. 2020;38(15_suppl):e15594). We would like to thank Dr. James Duncan and Dr. Jake Turowec for their expert insights on high-throughput genomic and proteomic data as it pertained to this manuscript.

\section{AUTHOR CONTRIBUTIONS}

SS, DL and LG collectively conceived the aim, scope and content of this publication. SS performed the systematic data collection and drafting of the manuscript, with input and consultation from all authors. All authors discussed the results and contributed to the final manuscript.

\section{FUNDING INFORMATION}

This work has been supported by grants from the Canadian Institutes of Health Research (CIHR; DL: FRN \#37854; FRN \#148605).

\section{ETHICS APPROVAL AND CONSENT TO PARTICIPATE} Not applicable.

\section{CONSENT FOR PUBLICATION}

Not applicable.

\section{COMPETING INTERESTS}

The authors declare no competing interests. 


\section{ADDITIONAL INFORMATION}

Supplementary information The online version contains supplementary material available at https://doi.org/10.1038/s41416-021-01616-2.

Correspondence and requests for materials should be addressed to Scott W. Strum or David W. Litchfield.

Reprints and permission information is available at http://www.nature.com/ reprints

Publisher's note Springer Nature remains neutral with regard to jurisdictional claims in published maps and institutional affiliations.
Open Access This article is licensed under a Creative Commons cc) Attribution 4.0 International License, which permits use, sharing,
adaptation, distribution and reproduction in any medium or format, as long as you give appropriate credit to the original author(s) and the source, provide a link to the Creative Commons license, and indicate if changes were made. The images or other third party material in this article are included in the article's Creative Commons license, unless indicated otherwise in a credit line to the material. If material is not included in the article's Creative Commons license and your intended use is not permitted by statutory regulation or exceeds the permitted use, you will need to obtain permission directly from the copyright holder. To view a copy of this license, visit http://creativecommons. org/licenses/by/4.0/.

(c) The Author(s) 2021 